\title{
Sketsa Normatif dan Empirik Persoalan Negara dan Pemerintahan di Kalangan Umat Islam
}

\author{
Ridwan
}

\begin{abstract}
The state institution and the govermment in Islam is the instrument of application of the part in Islamic tenet. Because the part of Islamic tenet have to be applied in human life, while for the application of Islamic tenet need the state instrument and govemment, so the existence of this instrument is unavoidable. The Moslem must create the model, form, state system and government according with the situation and condition faced by the Moslem. The Islamic tenet teach only the general principles on state establishment and running the government. Now, the form, model and system of state and govermment is applicable, as long as it relevant with the principles of Islamic tenet.
\end{abstract}

\section{Pendahuluan}

Melalui al-Quran yang merupakan kalam Allah manusia dapat mengetahui apa kehendak Allah yang harus diimplementasikan dalam kehidupannya. Allah telah menentukan bahwa manusia diciptakan untuk mengabdi kepada-Nya dalam berbagai dimensi kehidupannya. Upaya menciptakan tatanan sosial yang mampu menopang proses pengabdian itu menjadi kewajiban manusia untuk mewujudkannya. Pada kenyataannya, upaya menciptakan tatanan sosial seperti itu tidak mudah diwujudkan karena ternyata alQuran tidak menjelaskan dan merinci semua persoalan yang dihadapi umat manusia. Sunah dan Hadits-hadits Nabi, selaku praktek dan penjelas kandungan al-Quran, hadir dalam situasi kesejaraah tertentu yang untuk beberapa hal terikat dengan situasi dan kondisi yang dihadapi Nabi Muhammad pada saat tersebut. Dengan kata lain, ada persoalanpersoalan baru sejalan dengan perkembangan kehidupan manusia yang tidak disebutkan al-Quran dan tidak dijelaskan oleh Nabi. Di sisi lain, kaum muslimin meyakini Islam sebagai agama samawi terakhir yang sempurna, lengkap, mengatur semua dimensi kehidupan manusia, dan berlaku sepanjang zaman. Sebagai agama yang berlaku sepanjang zaman, Islam memiliki sifat fleksibel dalam mengatur hal-hal yang terkait dengan perubahan dan dinamika kehidupan manusia, sementara terhadap hal-hal yang tidak terkait dengan perubahan dan dinamika manusia Islam mengatur secara tegas dan baku. Dengan bersandar pada proposisi ini, para yuris muslim menciptakan kaidah; tauqif dan taghayyur atau ghair ma'kulat al-ma'na dan ma'kulat al-ma'na, yang pertama disebut 
ibadah ritual (mahdhah), sedang yang kedua ibadah sosial (ghair mahdhah) atau mu'amalah. Melalui pembagian inilah lahir kaidah; "prinsip dalam ibadah adalah batal sampai tegak dalil yang memerintahkan" dan 'prinsip dalam mu'amalah atau adat adalah sah sampai tegak dalil yang membatalkan atau mengharamkannya".' Dengan bersandar pada kaidah ini, kaum muslimin meyakini bahwa hal-hal yang tidak terkait dengan perubahan dan perkembangan, khususnya ibadah mahohhah, al-Quran dan Hadis Nabi telah menjelaskan secara rinci dan baku, yang tidak memungkinkan adanya perubahan, penambahan, maupun pengurangan. Dalam hal ini kreasi pemikiran manusia tidak dapat dilibatkan (ghair ma'kulat al-ma'na), manusia hanya tinggal melaksanakan apa yang sudah ditentukan Allah dan Rasul-Nya. Sedangkan untuk hal-hal yang terkait dengan perubahan dan perkembangan, al-Quran dan Hadis Nabi hanya memberikan prinsip-prinsip umum, dan perinciannya diserahkan kepada kreasi dan ijthad manusia.. Bidang politik atau masalah negara dan pemerintahan merupakan persoalan yang terkait dengan perubahan dan perkembangan atau termasuk sebagai bagian dari mu'amalah. ${ }^{2}$ Pada bidang ini al-Quran tidak mengatur secara rinci, karena; pertama, al-Quran pada prinsipnya adalah petunjuk etik bagi manusia, ia bukanlah sebuah kitab ilmu politik; kedua, sudah merupakan suatu kenyataan bahwa institusi-institusi sosio-politik dan organisasi manusia selalu berubah dari masa ke masa, dengan kata lain, diamnya alQuran berarti memberikan jaminan yang sangat esensial dan sengaja terhadap kekakuan hukum dan sosial. ${ }^{3}$ Menurut Asad, "Karena metoda politik itu dimaksudkan agar sesuai dengan perkembangan kondisi dan waktu, maka ia hanya dikemukakan secara garis besar dan tidak dalam detail-detailnya. Kebutuhan politis manusia merupakan kebutuhan yang selalu terikat dengan waktu dan selamanya berubah seirama dengan perubahan dan perjalanan waktu itu sendiri. Sistem-sistem dan hukum-hukum yang ditetapkan secara kaku, pasti tidak akan sesuai dengan hukum alam yang selalu berubah dan berkembang. ${ }^{4}$ Tulisan sederhana ini akan memaparkan secara singkat persoalan negara dan pemerintahan di kalangan umat Islam, khususnya dari aspek hukum.

'Al-ashl fi al-ibadat al-buthlan hatta yaquma dalilun 'ala al-amr, dan Al-Ashlfi al-mu'amalat shihhah hatta yaquma dalilun 'ala al-buthlan wa al-tahrim, Abd al-Hamid Hakim, al-Bayan, Nusantara, Bukit Tinggi, tt., hlm. 209, bandingkan dengan Khalid Abdullah 'led, Mabadial-Tasyrial-Islamy (Syirkat al-Hilal al-'Arabiyah, 1986), him. 118-119

${ }^{2}$ Fakta bahwa masalah ini termasuk dalam bidang mu'amalah dapat dilihat pada, Abd al-Wahab Khalaf, IImu Ushul al-Fiqh (Kuwait Dar at-Qalam, 1978), hlm. 33, Wahbah al-Zuhaily, al-Qur'an Bunyatuh al-Tasynityyah wa Khashaishuh al-Hadhariyyah (Bairut: Dar al-Fikr al-Mu'ashirah, 1993), hlm. 29, Muhammad Abu Zahrah, Ushul al-Figh (Dar al-Fikr al-Araby, tt.), hlm. 99-101. Khusus di kalangan syi'ah, persoalan imamah dianggap sebagai bagian dari keimanan, bahkan diyakini sebagai salah satu rukun iman, karena itu dikaji dalam teologi, bukan kajian hukum atau figh. Lhat Abd al-Karim al-Syahrastani, al-Milal wa al-Nihal (Bairut Dar al-Fikr, tt), hlm. 146. Muhammad Husein al-Dzahabi, al-Tafsirwa al-Mufassirun, Juz Il, (Bairut Dar al-Fikr, 1976), hlm. 8

${ }^{3}$ Ahmad Syafii Maarif, Islam dan Masalah Kenegaraan (Jakarta: LP3ES, 1987), hlm.16

"Muhamad Asad, Sebuah Kajian fentang Sistem Pemerintahan Islam (Bandung: Bandung Pustaka) hlm. 45 
Islam dan Institusi Politik

Setelah menyebutkan bahwa pelaksanaan berbagai ketentuan yang terdapat dalam al-Quran dan Hadis, selamanya akan tetap merupakan teori sepanjang belum ada satu kekuasaan zamani (duniawi) yang bertanggungjawab merealisasi syari'at Islam, Asad menegaskan bahwa membentuk negara atau beberapa negara yang islamis merupakan syarat yang tidak boleh tidak harus ada dalam kehidupan yang islamis dalam arti yang sebenarnya. ${ }^{5}$ Proposisi ini memiliki sandaran otoritatif pada praktek kehidupan Nabi Muhammad di Madinah. Nabi Muhammad ketika di Madinah telah membuat Piagam Madinah, sebagai aturan main kehidupan masyarakat Madinah yang pluralistik sehingga tercipta masyarakat yang teratur, dan dalam piagam itu tertulis bahwa Nabi Muhammad diangkat sebagai pemimpin mereka, yang diberi wewenang untuk menyelesaikan perbedaan pendapat dan pertikaian yang timbul di antara penandatangan piagam. Di Madinah inilah muncul negara Islam pertama dan telah terpenuhi unsur-unsur negara seperti ada rakyat, wilayah, dan pemerintah, ${ }^{6}$ atau setidak-tidaknya memiliki ciri-ciri institusi negara sebagaimana yang dikenal sekarang. Muhammad bukan hanya bertindak sebagai utusan Allah yang menyampaikan wahyu tetapi juga sebägai kepala negara yang mengatur berbagai persoalan masyarakat dan negara, bahkan diyakini sebagai kepala negara yang pertama dalam sejarah Islam.' Praktek kehidupan Muhammad secara tegas menunjukan perpaduan antara agama dan negara. Dalam konteks inilah ungkapan "Islam adalah agama dan negara" mempunyai pijakan otoritatif. Suatu ungkapan yang secara tegas menolak adanya sekularisasi dalam Islam. Rahman menyebutkan bahwa "antara agama dan politik tidak dapat dipisahkan ${ }^{n},{ }^{8}$ atau menurut Taimiyah, "imamah adalah alat untuk memelihara iman".9 Suatu ungkapan yang dengan tegas menunjukan bahwa institusi negara dan pemerintahan merupakan faktor penting dalam ajaran Islam. Hanya saja harus buru-buru digarisbawahi bahwa negara dalam ajaran Isiam hanyalah alat bagi tegaknya agama.

Meskipun institusi kekuasaan merupakan faktor penting bagi tegaknya agama, akan tetapi al-Quran dan Hadits-hadits Nabi tidak menentukan secara baku dan rinci tentang bentuk pemerintahan, organisasi-organisasi kenegaraan, perangkat pemerintahan, dan hal-hal teknis lainnya. Al-Quran dan Haditshadits Nabi hanya menyebutkan prinsip-prinsip yang akan menjadi pijakan kehidupan negara

\footnotetext{
s/bid., him. 8

6Mahmud Hilmi, Nidham al-Hukmi al-Islamy (Kairo: Dar al-Huda, 1978), hlm. 25

${ }^{7} \mathrm{Abd}$ al-Qadir Audah, al-Islam wa Audha'una al-Siyasiyah (Kairo: al-Mukhtar al-Islamy, tt), hịm 95-96, Shofi Hasan Abu Thalib, Tathbiq al-Syari'at al-Islamiyah fi al-Bilad al-'Arabiyah (Kairo: Dar al-Nahdhah al-'Arabiyah, 2001), hlm. 102, J. Suyuti Pulungan, Prinsip-prinsip Pemerintahan dalam Piagam Madinah (Jakarta: Rajawali Press, 1994), hlm. 2. Lihat juga Imam Khomeini, Sistem Pemerintahan Islam (Jakarta: Pustaka Zahra, 2002).

${ }^{8}$ M. Hasbi Amirudin, Konsep Negara Islam Menunt Fazlur Rahman (Yogyakarta: Ull Press, 2000), hlm. 80

${ }^{9}$ Qamaruddin Khan, Pemikiran Politik Ibmu iammyalı (Bandung: Bandung Puslaka, 2001). hlm. 75
} hlm. 26 
dan pemerintahan bagi umat Islam di manapun dan kapanpun..$^{10}$ Dengan berpijak pada prinsip-prinsip dalam al-Quran dan Hadits-hadits Nabi, umat Islam memiliki keleluasan untuk menciptakan model dan sistem negara dan pemerintahan sesuai dengan situasi dan kondisi yang dihadapi umat Islam.

\section{Hukum Membentuk Negara dan Mengangkat Imam}

Pertanyaan tentang apakah institusi imamah (negara) merupakan kewajiban agama atau bukan telah muncul sejak lama. Dengan mengecualikan pendapat minoritas," umat Islam sepakat akan wajibnya menegakan negara dan mengangkat imam. Pendapat alMawardi, yang menyebutkan bahwa imamah diwujudkan untuk mengganti tugas kenabian dalam menjaga agama dan mengatur dunia, ${ }^{12}$ jelas-jelas menunjukan bahwa institusi imamah merupakan kewajiban agama. Begitu pula pendapat al-Ghazali, yang menyatakan bahwa agama adalah dasar, dan pemerintah adalah penjaganya ${ }_{1}{ }^{13}$ atau pendapat Taimiyah, yang menegaskan bahwa kekuasaan politik (negara) bagi kehidupan masyarakat merupakan salah satu kewajiban sangat penting agama, bahkan agama tidak dapat tegak tanpa topangan negara, ${ }^{14}$ atau dalam ungkapan lain, memimpin dan mengendalikan rakyat adalah kewajiban asasi dalam agama. Bahkan iqamatuddin tidak mungkin direalisasikan kecuali dengan adanya kepemimpinan. Maka wajib untuk membentuk sebuah imamah dalam rangka realisasi spiritual dan mendekatkan diri kepada Allah. ${ }^{15}$ Yusuf Musa menegaskan bahwa, "Pengangkatan imam bagi kaum muslimin merupakan tujuan terpenting dari Islam, sehingga secara syariat adalah merupakan kewajiban 'keagamaan". ${ }^{86}$

${ }^{10}$ Lihat Muhammad Husein Haikal, al-Hukumah al-Hslamiyyah (Mesir: Dar al-Ma'arif, tt), hlm. 32, Muhammad Jalal Syaraf dan Ali Abd al-Mu'thi, al-Fikr al-Siyasi fi al-Islam (lskandariyyah: Dar al-Jami'at al-Mishriyyah, 1978), hlm. 62, dan Muhammad al-Mubarak, Nidhamal-ssam; al-Hukm wa al-Daulah (Dar al-Fikr, 1989), hlm. 29

${ }^{11}$ Ada segolongan kecil umat Islam yang menganggap bahwa menegakan negara dan mengangkat imam itu tidak wajib seperti golongan al-Najdat dari sekte khawarij dan al-Asham dari muktazilah. Mereka mengatakan bahwa yang wajib adalah melaksanakan hukum-hukum syara'. Artinya bila umat telah dapat menikmati hidup adil, hukum-hukum Allah dapat terlaksana, tidak diperlukan adanya imam dan tidak wajib mengangkatnya, Ahmad Azhar Basyir, Masalah Imamah dalam Filsafat Politik Islam (Yogyakarta: UII Pers, 1988), hlm. 13, lihat juga Dhiauddin Rais, Teori Politik Islam (Jakarta: Gema Insani Press, 2001), hlm. 105. ar-Anshary menyebutkan alasan kelompok ini bahwa umat Islam memiliki kebebasan dalam menegakkan negara sesuai dengan kondisi dan kebutuhan mereka, yang dalam hal ini umat Islam tidak berdosa dan tidak dikenai tanggung jawab bila tidak menegakkan negara dan mengangkat imam, 'Abd al-Hamid Ismail al-Anshary, Nidham al-Hukm fi al-Islam (Qatar: Dar al-Qatar al-Fujaah, 1985), him. 107

${ }^{12}$ Al-Mawardi, al-Ahkam al-Sulthaniyah (Bairut: Dar al-Fikr, tt), hlm. 5

${ }^{13}$ Shofi.Hasan Abu Thalib, loc. cit., hlm. 114

${ }^{14}$ Dikutip dari Wahbah al-Zuhaily, al-Figh al-tslamy wa Adilatuh, Jilid VI (Bairut: Dar al-Fikr, 1989), him. 662-663

${ }^{15}$ Ibnu Taimiyah, Siyasah Syariyah, Etika Politik Islam (Surabaya: Risalah Gusti, 1995), hlm. 156-158

${ }^{16}$ Muhammad Yusuf Musa, Politik dan Negara dalam Islam (Surabaya: al-Ikhlas, tt), hlm. 37 
Di kalangan ulama, kewajiban membentuk negara dan mengangkat imam ini didasarkan pada beberapa alasan yaitu; pertama, ijma atau kesepakatan, sebagaimana ditunjukan para sahabat sepeninggal Muhammad. Mereka bermusyawarah di Saqifah Bani Saidah untuk memilih siapa pengganti Nabi dalam kedudukannya sebagai pemimpin masyarakat Islam, dan saat itu yang terpitih adalah Abu Bakar Siddik. ${ }^{17}$ Dalam hal ini, Ibnu Khaldun menulis, "jabatan imam wajib hukumnya, di mana hukum wajibnya dalam syara ditetapkan melalui ijma para sahabat dan tabi'in, sebab seiring dengan wafatnya Rasulullah para sahabat segera membai'at Abu Bakar Shiddik lalu menyerahkan persoalan mereka kepadanya. Demikian pula halnya yang tejadi pada masa-masa sesudahnya; tidak pernah barang sedetik pun ummat dibiarkan kacau tanpa pimpinan. Ketatapan yang diambil melalui ijma' ini membuktikan wajibnya fungsi seorang imam ${ }^{\mathrm{m}}{ }^{18}$ kedua, menghindari bahaya anarki. ${ }^{19}$ Menurut Abu Ya'la, akan muncul bencana bila tidak ada pemimpin yang melaksanakan urusan umat. ${ }^{20}$ Yusuf Musa mengatakan, pengangkatan imam adalah untuk menghindarkan bahaya yang diperkirakan akan terjadi, sedangkan menghilangkan bahaya ini menurut agama wajib. Tujuan penetapan hukum seperti muamalah, nikah, jithad, pidana, pengaturan hari raya dan jum'ah seiuruhnya dimaksudkan untuk memberikan kemaslahatan dunia dan akhirat kepada manusia. Tujuan semacam ini hanyalah terwujud dengan sempurna kalau ada imam; ${ }^{21}$ ketiga, melaksanakan berbagai kewajiban dan merealisir keadilan yang sempurna. ${ }^{22}$ Muhammad Mubarak menyebutkan, dalam al-Quran terdapat berbagai kewajiban yang tidak terbayangkan pelaksanaannya tanpa kehadiran pemerintah seperti hukuman had bagi pembunuh (qishash), potong tangan bagi pencuri, hukuman bagi pembuat onar di muka bumi, dan lain-lain. Dalam al-Quran juga terdapat hukum-hukum yang terkait dengan harta kekayaan, warisan, pembagian zakat, yang menuntut kehadiran penguasa untuk mengaturnya. Di samping itu, dalam al-Quran ada kewajiban amar ma'ruf nahy munkar dan jihad fi sabilillah serta hal-hal yang terkait dengannya seperti pernyataan perang, pembagian rampasan perang, tawanan perang, tebusan tawanan, dan sebagainya, yang kesemuanya menuntut kehadiran pemimpin. ${ }^{23}$

${ }^{17}$ Wahbah al-Zuhaily, op. cit., hlm. 664, al-Anshary, op. cit., hlm. 103, Dhiauddin Rais, op. cit., hilm. 94, Shofi Hasan Abu Thalib, op. cit., hlm. 105

${ }^{18}$ Dikutip dari Dhiauddin Rais, Islam dan Khilafah Kritik terhadap Buku Khilafah dan Pemerintahan dalam Islam, Ali 'Abdur Raziq (Bandung: Pustaka, 1985), hlm. 172

"Al-Anshary, op. cit., him. 104, Dhiauddin Rais, op. cit., hlm. 96-97, Wahbah al-Zuhaily, op. cit., hlm. 666, Shofi Hasan Abu Thalib, op. cit., hlm. 114

${ }^{20}$ Abu Ya'la, al-Ahkam al-Sulthaniyah (Bairut: Dar al-Fikr, 1994), hlm. 23

${ }^{21}$ Muhammad Yusuf Musa, op. cit., hlm. 36-37

${ }^{22}$ Al-Anshary, op. cit., hlm. 105,

${ }^{23}$ Muhammad al-Mubarak, op. cit., hlm. $12 \cdot 13$ 
Berbagai kewajiban dan penetapan hukuman tersebut tidak dapat dilaksanakan secara perorangan, sebab bila dilakukan secara perorangan akan melahirkan kekacauan di tengah masyarakat. Penetapan dan pelaksanaan hukuman haruslah ditempuh melalui sistem peradilan yang didasarkan pada syariat Islam, yang menjadi kewajiban imam untuk merealisirnya. Menurut Dhiauddin, keadilan yang sempuma tidak akan terwujud, manusia tidak akan terjamin kebahagiaan dunia dan akhiratnya, persatuan mereka tidak akan tercapai, serta segala urusan mereka tidak akan teratur, kecuali dengan adanya sistem pemerintahan, seperti imamah, yaitu pemerintahan islam yang berlandaskan pada asas agama. ${ }^{24}$

Telah disebutkan bahwa dalam al-Quran tidak terdapat perintah yang tegas untuk membentuk negara dan mengangkat imam, yang ditemukan hanyalah prinsip-prinsipnya. Salah satu prinsip dari al-Quran adalah QS, 4:58 dan 59, yang dalam hal ini, pakar tafsir Rasyid Ridha berpendapat, "Seandainya tidak ada ayat lain yang berbicara tentang pemerintahan, maka kedua ayat ini telah memadai", ${ }^{25}$ dan khususnya ayat 59 mengisyaratkan adanya lembaga legislatif dan lembaga eksekutif, yang dikenal sekarang. ${ }^{26}$ Seperti halnya dalam al-Quran, dalam Haditshadits Nabi pun tidak ada perintah tegas untuk membentuk negara dan mengangkat imam. Namun demikian, Hadits-hadits Nabi yang menyebutkan; "tidak halal bagi tiga orang yang berada di sesuatu tempat yang lapang (tempattempat yang berbahaya), melainkan mereka harus mengangkat salah seorang dari mereka untuk menjadi amir", atau hadis nabi yang berbunyi; "Apabila tiga orang pergi bersafar, hendaklah mereka mengangkat salah seorang untuk menjadi amir (pimpinan rombongan), mengisyaratkan perlunya kehadiran negara dan imam. Terhadap hadis tersebut para ulama berkata, bila terhadap tiga orang saja sudah diwajibkan memilih pimpinan, maka pada jamaah yang besar memilih pemimpin tentu lebih diwajibkan. Inilah dalil yang dipegang ulama dalam mewajibkan kita mengangkat kepala negara, gubernur, walikota, dan hakim. Lebih lanjut disebutkan, bahwa dengan memperhatikan sejarah Islam sejak dari zaman Rasul dan para sahabat serta apa yang dirundingkan mereka dalam Saqifah Bani Saidah, nyatalah bahwa seluruh sahabat sepakat tentang periu adanya khalifah yang mengganti kedudukan Rasul dalam urusan umat dan memelihara agama. Maka oleh karenanya dalil yang terkuat untuk menetapkan wajib adanya kepala negara ialah: ijma para sahabat, di samping dalil-dalil yang lain. ${ }^{27}$

Bila mencegah bahaya anarki, merealisir kewajiban agama, mewujüdkan keadilan, dan lain-lain itu merupakan kewajiban agama, sedangkan hal-hal tersebut tidak akan terwujud tanpa kehadiran negara dan imam, yang merupakan sarana dan syarat utama terealisimya hal-hal tersebut, maka menegakan

\footnotetext{
24.Dhiauddin Rais, op. cit., him. 102

rs Oikutip dari M. Quraish Shihab, Tafsir Al-Misbah, vol. II, Lentera Hati, Jakarta, 2000, hlm. 462

${ }^{28}$ Bandingkan dengan Mustafa al-Maraghi, Tafsir al-Maraghi, Julid li, Dar al-Fikr, Bairut, t., him. 73

${ }^{27}$ Tengku Muhammad Hasbi Ash Shiddieqy, Koleksi Hadits Hukum, juz 9, Pustaka Rizki Putra, Semarang, 2001, hlm. 457-459
} 
negara dan mengangkat imam itu menjadi kewajiban pula. Bila keberadaan suatu negara itu adalah keniscayaan bagi terealisimya ajaran-ajaran Islam, maka tak pelak lagi upaya mewujudkannya menjadi niscaya bagi setiap muslim dimanapun dan kapanpun. Dalam kaidah fiqh disebutkan; ma la yatimmu al-wajib illa bihi fahua wajib. ${ }^{28}$

\section{Aspek Teoretik dan Realitas Negara Islam}

Sejak runtuhnya kekhalifahan Turki Utsmani pada tahun 1924, umat Islam tidak lagi memiliki kekhalifahan universal, sementara umat Islam tersebar di wilayahwilayah teritorial tertentu atau negara-negara nasional, yang sebagian berada dalam cengkraman imperarialis Barat. Masingmasing negara nasional, terutama yang mayoritas muslim, sibuk dengan upaya membebaskan diri dari cengkraman imperialis Barat. Ketika sebagian negaranegara berpenduduk muslim tersebut meraih kemerdekaan, termasuk Indonesia, muncul pemikiran tentang bagaimana cara yang tepat untuk mengisi dan menjalankan negara merdeka, apa yang akan dijadikan dasar negara, predikat apa yang akan digunakan untuk suatu negara yang dijalankan berdasarkan ajaran Is- lam. Kelompok idealis tentu tidak ingin meniru. model negara-negara imperialis Barat. Sebagian kelompok muslim ingin menjadikan Islam sebagai aturan bernegara dan memberikan predikat negara Islam. ${ }^{29}$ Berdasarkan penelitian Juergensmeyer, "Kerinduan terhadap bentuk otentik politikreligius yang terbebas dari noda budaya Barat dikemukakan oleh banyak orang di negerinegeri yang telah merdeka pada abad ini" ${ }^{30}$ Namun ketika Islam akan dijadikan sebagai pedoman kehidupan bernegara, umat Islam menghadapi persoalan yang rumit, karena ternyata al-Quran dan hadits-hadits nabi hanya menetapkan prinsip-prinsip umum dan multiinterpretasi, sehingga tidak langsung aplikatif. Seiring dengan fakta ini, muncul pula terpaan budaya dan filsafat Barat yang begitu dahsyat sehingga mengaburkan sejarah islam tentang integrasi antara agama dan institusi kekuasaan. Akibat lebih lanjutnya adalah muncul sekelompok orang yang beranggapan bahwa ajaran Islam tidak ada sangkut pautnya dengan institusi negara. Sebagian muslim yang terilhami oleh konsep Barat dengan setia mengekor pada pemikiran Barat yang sekularistik, padahal bingkai sekularisme yang berasal dari dunia kristen ini jelas-jelas tidak dapat diterima dan diterapkan dalam ajaran Islam. Secara hukum, menganggap institusi

${ }^{20}$ Muhammad Abd al-Qadir Abu Faris, al-Nidham al-Siyasiffal-Islam, (1980), hlm. 163 dan Abd al-Qadir Audah, op. cit., him. 113

${ }^{29}$ Untuk kasus Indonesia, paparan lengkap tenlang masalah ini antara lain dapat dibaca pada, Deliar Noer, Partailslam di Pentas Nasional (Jakarta: Grafiti Pers, 1987), Ahmad Syafii Maarif, Islam dan Masalah Kenegaraan (Jakarta: LP3ES, 1987), Islam dan Politik di Indonesia Pada Masa Demokrasi Terpimpin (Yogyakarta: IAIN Sunan Kalijaga Press, 1988), Bahtiar Effendy, Islam dan Negara Tranformasi Pemikiran dan Praktek Politik Islam dilndonesia (Jakarta: Paramadina, 1998).

${ }^{30}$ Mark Juergensmeyer, Menentang Negara Sekular, Kebangkitan Global Nasionalisme Religius (Bandung: Mizan, 1998), hlm. 13 
negara dan pemerintahan sebagai sesuatu yang terpisah secara tegas dari agama atau pendapat bahwa Islam tidak ada sangkut pautnya negara institusi negara adalah anggapan dan pendapat yang a historis dan tidak memiliki pijakan dalam pemikiran Isiam. Bahkan dapat dikatakan bahwa anggapan demikian muncul dari orang-orang yang enggan memahami Islam secara kontekstual. Telah disebutkan bahwa persoalan negara dan pemerintahan merupakan bagian dari mua'malah. Dan mua'malah adalah bagian tak terpisahkan dari syariat Islam, karena itu dalam ajaran islam antara agama dan institusi kekuasaan bukanlah sesuatu yang harus dipertentangkan tetapi harus diupayakan untuk dipersandingkan. Telah disebutkan, dalam Islam terdapat nilai-nilai dan prinsip-prinsip umum tentang penataan kehidupan semua dimensi manusia, termasuk dimensi politik. Kewajiban menggali nilai-nilai. dan prinsipprinsip Islam untuk dijadikan acuan dalam penyelenggaraan negara dan pemerintahan ini terietak di pundak kaum muslimin.

Di samping faktor ekstenal, pengaruh budaya dan pemikiran Barat, yang menghambat perwujudan negara yang berdasarkan Islam atau integrasi antara agama dan institusi kekuasaan, ada pula faktor internal yaitu pertentangan di antara kaum muslimin, bahkan pertumpahan darah. Syahrastani mengatakan, "pertentangan paling besar di kalangan umat adalah pertentangan masalah imamah atau pemerintahan, sehingga pedang tidak terhunus karena persoalan pokok keagamaan tetapi justru karena persoalan pemerintahan di setiap zaman. ${ }^{31}$ Sejarah mencatat ada "sejarah hitam" yang- sangat mengenaskan di kalangan umat Islam, karena persoalan politik. ${ }^{32}$

Persoalan lain yang dihadapi umat Islam di negara-negara nasional yang baru lahir adalah persoalan warisan fiqh klasik, yang menentukan bahwa tidak boleh mengangkat dua imam apalagi lebih dalam satu waktu. ${ }^{33}$ Ketidakbolehan mengangkat dua imam atau lebih dalam satu waktu ini sudah barang tentu sudah tidak relevan lagi dengan lahirnya negara-negara nasional yang dibatasi oleh teritorial tertentu. ibnu Taymiyah dan beberapa ulama lainnya membolehkan mengangkat imam lebih dari satu dalam satu waktu. Menurut Ibnu Taimiyah, umat Islam tidak wajib mempertahankan kesatuan khalifah yang universal. Dia percaya, adalah mungkin adanya imam lebih dari satu yang memerintah dalam

"Abd al-Karim al-Syahrastani, op. cit,, hlm. 22

${ }^{32}$ Sejarah hitam yang dimaksud antara lain adalah peristiwa terbunuhnya Usman bin Affan, yang memicu terjadinya "Perang Jamal", dan peristiwa "Perang Siffin" pada masa Ali bin Abi Thalib, yang menimbulkan banyak korban, terbunuhnya Imam Husein di Karbala oleh Yazid, dan berbagai peristiwa tragis lainnya, yang semuanya menyangkut persoalan politik. Cerita lengkap "sejarah hitam" umat islam ini dapal dibaca pada, Abul A'la Maududi, Khilafah dan Kerajaan (Bandung: Mizan, 1994), Imam al-Suyuti, Tarikh Khulafa' (Jakarta: Pustaka Kautsar, 2001), dan beberapa buku sejarah lainnya.

${ }^{3} \mathrm{Al}$-Mawardi, op. cit., hlm. 9. Beberapa pendapat ulama klasik yang tidak membolehkan adanya dua imam alau lebih dalam satu waktu ini dapat dilihat pada Abd al-Qadir Abu Faris, op. cil., hlm. 164-166, dan Muhammad bin Idris al-Syafi'i, al-Kaukab al-Azhar, Syarh al-Fiqh al-Akbar (Bairut: Dar al-Fikr, t), hlm. 149, Abu Ya'la, op. cit., him. 30 
waktu bersamaan. Hal ini menjustifikasi keberadaan negara-bangsa islam, dengan menentang negara Islam yang universalistik dalam sejarah. ${ }^{34}$

Secara ideal, negara Islam meliputi semua negara yang diatur dengan syariat Islam atau warga negara muslim dapat melaksanakan hukum Islam di negara itu. ${ }^{35}$ Suatu negara disebut negara Islam, ketika kaum muslimin memiliki kekuasan di atas wilayah itu, kaum muslimin memiliki keleluasan untuk meninggikan hukum Islam dan syiar Islam. ${ }^{36}$ Ada tiga ciri negara dalam suatu negara Islam, yaitu masyarakat muslim (ummah), hukum Islam (syariah), dan kepemimpinan masyarakat muslim (khalifah). Karena kekuasaan mutlak atau kedaulatan puncak ada pada Allah, maka negara Islam harus menjunjung tinggi keunggulan hukum
Islam, dan karena masyara-kat muslim harus diperintah menurut hukum Islam, maka harus mempunyai pemimpin untuk melaksanakan atau menjalankannya. ${ }^{37}$ Bagaimanapun juga, negara nasional muslim bukan merupakan negara islam jika tidak memakai metode pemerintahan Islami. Negara nasional muslim hanya dapat dinyatakan sebagai negara Islam apabila konstitusinya benar-benar patuh kepada prinsip-prinsip kedaulatan penuh Allah dan keunggulan syariah..$^{38}$ Upaya menerapkan syariah Islam dan mewujudkan negara Islam ini menjadi kewajiban bagi setiap muslim. Menurut Zallum, seluruh kaum muslimin sebagai pribadi, jama'ah, dan negara, hukumnya wajib menerapkan hukum Islam secara menyeluruh. Lebih lanjut disebutkan, tidak ada alasan bagi negara yang ada di dunia Islam untuk tidak menerapkan

${ }^{3}$ Abdullah Ahmed An-Naim, Dekonstruksi Syariah (Yogyakarta: LKIS, 1994), hlm. 73, lihat juga Dhiauddin Rais, op. cit., hlm. 164

${ }^{35}$ Khalid Abdullah 'led, op. cit., hlm. 176

${ }^{36}$ Said Ramadhan al-Buthi, al-Vihad fi al-Islam, Kaifa Nafhamuhu wa Kaifa Numarisuhu (Bairut: Dar al-Fikr al-Mu'ashirah, 1993), hlm. 80

${ }^{3}$ Hakim Javid Iqbal, Konsep Negara dalam Islam, tulisan pada buku, Masalah-masalah Teori Politik Islam, Mumlaz Ahmad (Ed.), (Bandung: Mizan, 1994), hlm. 58. Adanya unsur khalifah dalam negara Islam, selaku pihak yang diberi wewenang menjalankan tugas-tugas kenabian atau menjalankan syariat Islam, maka syaratsyaratkhalifah atau kepala negara yang ditawarkan kitab-kitab fikih itu menjadi kemestian untuk direalisasikan. Dalam berbagai buku disebutkan bahwa syarat-syarat imam atau kepala negara yaitu antara lain; pertama, memiliki kemampuan umum dan ia seorang muslim, merdeka (bukan budak), laki-laki, dewasa, dan berakal sehat atau berilmu sehingga mampu berijtihad; $k e d u a$, adil dalam arti umum, memiliki kepribadian yang kuat, dan memiliki akhlak mulia serta dapat dipercaya; ketiga, memiliki kecakapan dan kemampuan dalam bidang-bidang hukum, peradilan, administrasi, dan tugas-tugas pemerintahan lainnya; keempat, memiliki fisik yang sehat dan sempurna serta memiliki keberanian dalam bertindak dan menghadapi musuh; kelima, keturunan quraisy. Syarat-syarat ini diambil dari Wahbah Zuhaily, al-Figh..., op. cit., hlm. 693-695, al-Mawardi, op. cit., hlm. 6, Abu Yala, op. cit.. hlm. 24, Abo al-Qadir Audah, al-Islam..., op. cit., hlm. 117-120. Selain syarat laki-laki dan keturunan quraisy semuanya disepakti. Syarat keturunan quraisy untuk negara-bangsa saat ini menjadi tidak relevan. Kalaupun syarat quraisy ini didasarkan pada hadits, kita dapat mengatakan bahwa hadits ifu bersifat kondisional.

${ }^{38}$ Hakim Javid lqbal, ibid, him. 68-71 
hukum Islam. Dengan alasan belum mampu untuk menerapkannya atau kondisinya belum cocok untuk diterapkan hukum Islam atau karena alasan opini umum dunia tidak menerima penerapan hukum Islam, atau pun karena negara-negara besar tidak memberi kesempatan kepadakita untuk menerapkannya, atau alasan-alasan dan argumentasi lemah lainnya, yang tidak ada nilainya sama sekali. Siapa saja yang beralasan dengan alasanalasan itu, maka Allah swt sama sekali tidak akan menerimanya. ${ }^{39}$ Sesudah dunia Islam terbagi-bagi menjadi negara-negara nasional, umat Islam di masing-masing negara tersebut ada yang mayoritas dan tidak sedikit yang minoritas. Kewajiban untuk mengupayakan terwujudnya negara Isiam tidak hanya terletak pada umat Islam mayoritas, tetapi juga pada umat Islam minoritas. Taimiyah menegaskan, minoritas-minoritas muslim harus meneruskan syiar agama mereka sebelum mereka cukup kuat untuk mengambil alih kendali pemerintahan. Lebih lanjut disebutkan, mungkin sekali orang-orang muslim merupakan minoritas di negeri-negeri asing, tetapi janganlah mereka merasa puas dengan keadaan mereka itu dan berpangku tangan dalam keadaan tak berdaya. Mereka harus berjuang untuk-menjadi kuat dan menguasai keadaan dengan melakukan dakwah secara tekun dan terus menerus. ${ }^{40}$

Namun pada realitasnya, karena berbagai kerumitan dan ada kendala ekstemal dan internal, upaya mewujudkan negara Islam ideal yang memungkinkan semua warga negara menjalankan kewajiban secara Jeluasa dan memperoleh hak secara adil itu tidak mudah dilaksanakan. Oleh karena itu, dalam praktek sebutan dan katagori negara Islam itu tidak dalam arti ideal, tetapi hanya dilihat dari segi pelaksanaan dan penegakan syariat Islam ${ }^{41}$ atau lebih sempit lagi ajaran figh, yang karena itu definisi negara Islam di kalangan yuris muslim hanya berkisar pada persoalan penegakan dan pelaksanaan hukum. Perhatikanlah definisi berikut ini; Wahbah Zuhaily mengatakan bahwa negara Islam adalah negara yang (berada di bawah) tunduk pada kekuasaan negara muslim, di dalamnya tegak dan terlaksana hukum dan syi'ar-syi'ar Islam, sifat negara ini tidak berubah karena sebab tidak terlaksana atau tertundanya penerapan sebagian hukum-hukum Islam selagi syi'ar islam terlaksana seperti adzan, jum'ah, dan (shalat) jamaah. ${ }^{42}$ Menurut Audah, negara Islam meliputi negara-negara yang di dalamnya tampak (terlaksana) hukum-hukum Islam, atau warga negara muslim dapat melaksanakan hukum-hukum Islam. Termasuk negara Islam adalah semua negara yang mayoritas penduduknya muslim, semua negara yang dikuasai pemerintahan muslim meskipun mayoritas penduduknya non muslim. Termasuk pula negara Islam, yaitu semua negara yang dikuasai pemerintahan non muslim tetapi penduduk muslim dapat melaksanakan hukum-hukum Islam atau tidak ada larangan bagi kaum muslimin untuk

\footnotetext{
${ }^{39}$ Abdul Qadim Zallum, Sistem Pemerintahan Islam, al-Izzah, Bangil-Jatim, 2002, him. 297-299

${ }^{0}$ Qamaruddin Khan, 0p. cit., hlm. $72-73$

"Dale F. Eickelman dan James Piscatori, Politik Mulim, Wacana Kekuasaan dan Hegemoni dalam Masyarakat Muslim, Tiara Wacana, Yogyakarta, 1998, hlm. 35

¿Wahbah al-Zuhaily, al-Qur'an..., op. cit., hlm. 12
} 
melaksanakan hukum-hukum Islam. ${ }^{43}$

Pendefinisian negara Islam tersebut pada gilirannya menyimpan persoalan rumit yakni menyangkut kewajiban taat dari rakyat kepada pemimpin, yang dituntut oleh al-Quran dan hadits-hadits nabi. Wajibkah rakyat taat kepada pemimpin yang non islam, seperti definisi Audah di atas? Di samping itu, fungsi dan tugas imamah juga tidak dapat diwujudkan dengan sempurna. Telah disebutkan bahwa fungsi imamah adalah untuk mengganti tugas-tugas kenabian dalam menjaga agama dan mengatur dunia, dan tugas pemimpin adalah; pertama, menegakan agama Islam dan melaksanakan hukum-hukumnya; kedua, mengatur negara dalam batas-batas yang telah digariskan Islam. ${ }^{44}$ Dan tujuan negara menurut islam adalah terwujudnya masyarakat yang selalu mengamalkan kebajikan dan keadilan, membela kebenaran dan meruntuhkan kebatilan, dengan kata lain, satu masyarakat yang perupaya menciptakan satu kondisi sosial yang memberi kemungkinan seluas-luasnya kepada sebanyak mungkin anggota masyarakatnya untuk hidup sesuai dengan hukum fitrah yang datang dari Allah, baik aspek spiritual maupun aspek material. ${ }^{45}$ Apakah mungkin fungsi, tugas, dan tujuan ideal ini terealisir dalam suatu negara yang dikuasai oleh pemerintahan non muslim? Agaknya kita pesimis untuk mengatakan mungkin, apalagi bila menyimak pendapat Maryam Jamilah, yang mengatakan, "Aqidah takwa tak akan langgeng di bawah kepemimpinan tak bertuhan, dengan demikian, wajib atas oràng-orang yang bertakwa untuk membangun kepemimpinan takwa di dunia". ${ }^{46}$ Kepemimpinan takwa sudah barang tentu tidak dapat terwujud secara baik dan wajar bila dalam suatu negara itu hanya menekankan aspek figh semata-mata, tanpa penerapan ajaran Islam secara total dan komprehensif.

Melihat realitas yang dihadapi umat Islam di negara-negara nasional, yang mengalami kesulitan untuk mewujudkan negara Islam ideal yang mencakup aspek formal dan substansial, ada sebagian muslimin yang enggan menggunakan predikat negara Islam secara formal, karena; pertama, dianggap tidak menguntungkan ditinjau dari segi strategi dakwah, karena penggunaan predikat negara Islam secara formal secara langsung mendapatkan tantangan yang demikian keras bukan saja dari sebagian kaum muslimin sendiri tetapi lebih-lebih dari sebagian non muslim, yang mengidap stigma keliru ajaran Islam dan negara Islam. Mereka menganggap negara Islam itu identik dengan potong tangan, hukum bunuh bagi orang murtad, rajam, cambuk, cadar muslimah, dan lain-lain; kedua, kaum muslimin belum memiliki sandaran konsep dan teori yang disepakati bersama dan yang dapat diterapkan dalam sistem ketatanegaraan dan pemerintahan Islam; ketiga, sebagian kaum muslimin meyakini bahwa tidak ada preseden sejarah tentang

\footnotetext{
${ }^{43} \mathrm{Abd}$ al-Qadir Audah, al-Tasyri al-Jana'ial-Islamy Muqarninan bial-Qanun al-Wadhi, Jilid I, (Bairut: Dar ai-Katib al-'Araby, , tt., hlm. 267, lihat pula pada bukunya, al-Islam..., op. cit., hlm. 242

44 Abd al-Qadir Audah, al-Islam..., op. cit., him. 106

${ }^{45}$ Muhammad Asad, op. cit., him. 60

${ }^{45}$ Maryam Jamilah dalam buku, Benturan Barat-Islam (Randung: Mizan, 1982), him. 96
} 
predikat negara Islam secara formal. Nabi Muhammad dan para khulafau rasyidun pun tidak pernah menyebut wilayah kekuasaannya sebagai negara Islam. Kalaupun ada predikat negara Islam, hal ini hanya ditemukan dalam kitab-kitab fiqh yang dimaksudkan untuk membedakan dengan negara-negara bukan Islam, yaitu negara sahabat atau negara perjanjian (darul 'ahdi) dan negara perang atau negara musuh (darul harbi), dalam rangka pembahasan hubungan antar negara. ${ }^{47}$

Dengan berbagai alasan ini mereka menganggap bahwa yang terpenting adalah bagaimana tujuan-tujuan ajaran Islam itu dapat direalisasikan dalam kehidupan masyarakat. Atas dasar ini, negara bagi kaum muslimin tidak harus berpredikat negara Islam. Azhar Basyir berpendapat bahwa predikat negara menurut ajaran Islam bukanlah yang esensial, apapun predikat yang dipergunakan selagi mendukung asas dan tujuan negara, dapat dipandang memadai. Formalitas bukan selalu merupakan hal esensial dalam hidup manusia, yang esensial adalah materinyal substansinya. Hal ini dapat dibenarkan dalam ajaran Islam. Tanpa menyebut secara formal asas negara adalah al-Quran dan Sunah Rasul dan tujuan negara adalah terlaksananya ajaran al-Quran dan Sunah Rasul dalam masyarakat, selagi secara materil ajaran al-Quran dan Sunah Rasul mungkin terealisasikan secara legal, telah dapat dipandang memadai.48 Menurut Syafii Maarif, negara sebagai instrumen, tidak perlu bernama negara Islam. Untuk kasus Indonesia, negara Pancasila dapat dijadikan instrumen yang mantap untuk mencapai dan melaksanakan cita-cita moral Islam berupa kebebasan, keadilan, kemakmuran, persamaan, persaudaraan, dan lain-lain. ${ }^{49}$

Bila pemikiran ini kita sepakati, maka di dalamnya tersirat peluang untuk menggunakan model dan sistem Barat atau lainnya dalam penyelenggaraan negara dan pemerintahan. Dengan kata lain, apapun model dan sistem yang digunakan kaum muslimin dalam penyelenggaraan negara dan pemerintahan sepanjang nilai-nilai ajaran Islam mampu direalisir, maka hal ini dianggap telah memadai. Bila demikian halnya, maka ada komitmen dan beberapa upaya atau langkah yang harus ditempuh, yaitu; pertama, umat Islam di negara-negara yang bersangkutan harus memiliki komitmen bahwa penggunaan model dan sistem negara dan pemerintahan Barat atau lainnya itu sifatnya sementara, sebelum umat Islam mampu menciptakan sendiri model dan sistem yang selaras dengan ajaran Islam, dan umat Islam hanya memanfaatkan kerangkanya saja, tidak isi dan semangat yang ada di balik sistem dan model itu. Sementara, kalaupun umat Islam akan meniru model dan sistem yang pernah digunakan pada masa pemerintahan khulafaur rasyidun dari para penerusnya, maka model dan sistem itu harus dibaca konteks dan situasi kesejarahannya, karena tidak selamanya relevan dengan tuntutan situasi dan kondisi umat Islam saat ini; kedua, berbagai model dan sistem negara dan pemerintahan

\footnotetext{
"Ahmad Azhar Basyir, Negara dan Pemerintahan dalam Islam (Yogyakarta: Ull Press, 2000), hlm. 43

-Ahmad Azhar Basyir, ibid., hlm. 77-78

${ }^{49}$ Ahmad Syafii Maarif, al-Qur'an, Realitas Sosial dan Limbo Sejarah (Bandung: Mizan, tt). hlm. 65
} 
yang ada atau yang pernah ada di dunia ini selalu dibangun di atas konsep dan falsafah dari warga negara yang bersangkutan. Dengan begitu, penerapan model dan sistem pemerintahan yang ada atau pernah ada itu bagi umat Islam harus dibarengi dengan penggantian konsep dan falsafah yang sejalan dengan ajaran Islam. Peniruan model dan sistem pemerintahan Barat, misalnya, harus diiringi dengan penggantian konsep dan falsafah yang mendasarinya. Tanpa penggantian konsep dan falsafah yang sejalan dengan ajaran Islam, sangat mungkin akan melahirkan kontradiksi konseptual dan aktual dalam penyelenggaraan negara dan pemerintahan Islam.

Saat ini demokrasi merupakan wacana yang paling popular. Hampir setiap negara yang ada di dunia saat ini menempatkan demokrasi dalam penyeienggaraan negara dan pemerintahan, tidak terkecuali di kalangan kaum muslimin. Retorika banyak kaum nasionalis religius mengesankan bahwa mereka sangat antusias terhadap demokrasi. Bahkan kaum aktivis yang sangat menentang negara sekular pun menyatakan pentingnya semangat demokratis dalam politik. Syaikh Yasin, misalnya, mengatakan bahwa "Islam meyakini demokrasi". Seorang aktivis ikhwanul Muslimin menyatakan bahwa "Demokrasi adalah satu-satunya sistem bagi negara islam". 50
Benarkan negara Islam menghendaki sistem demokrasi, sebagaimana yang dikembangkan dan dipraktekkan di negaranegara Barat? Dengan kata lain, apakah penerapan demokrasi dalam negara Islam merupakan kemestian dan satu-satunya sistem bagi negara Islam? Bila jawabannya ya dan tanpa reserve, agaknya jawaban itu terlalu tergesa-gesa. Model dan sistem pemerintahan demokrasi Barat dengan berbagai derivasinya seperti pemisahan kekuasaan negara, perlindungan HAM, sistem pemilu, partisipasi publik, sistem perwakilan, dan sebagainya dibangun di atas konsep dan falsafah liberalisme, individualisme, dan sekularisme. ${ }^{51}$ Meniru model dan sistem demokrasi tanpa dibarengi dengan penggantian konsep dan falsafah yang sejalan dengan ajaran Islam sama maknanya dengan menciptakan kontradiksi konseptual dan aktual dalam penyelenggaraan negara dan pemerintahan Islam. Bila penerapan demokrasi dianggap sebagai kemestian bagi negara Islam dan diyakini sebagai tuntutan negara modem, maka penggantian konsep dan falsafah yang mendasari demokrasi itu merupakan kemestian bagi umat Islam. Dengan kata lain, harus diiringi dengan upaya membingkai sistem demokrasi itu dalam kerangka syariah. Sistem demokrasi yang bersandar pada suara mayoritas dalam

${ }^{50}$ Dikutip dari Mark Juergensmeyer, op. cit., hlm. 205

${ }^{51}$ Liberalisme adalah paham yang menghendaki demokrasi dan kebebasan pribadi untuk berusaha dan berniaga tanpa campur langan pihak pemerintah. Individualisme yailu paham yang mementingkan kebebasan pribadi untuk berbuat atau menganut kepercayaan tanpa campur tangan pihak lain, atau paham yang mementingkan orang perorang. Sekularisme adalah paham yang menganggap bahwa moralitas tidak perlu didasarkan pada ajaran agama, atau paham tentang pemisahan secara tegas antara urusan negara dengan urusan agama. 
penentuan kebijakan umum harus diarahkan dalam koridor ajaran Islam, sebab suara mayoritas tidak selalu mencerminkan kebenaran..$^{52}$ Konsep dan falsafah yang mendasari sistem demokrasi di Barat seperti liberalisme, individualisme, dan sekularisme jelas-jelas tidak sejalan dengan ajaran Islam. Mungkin karena keberatan untuk menggunakan sistem demokrasi dalam pengertian Barat, Maududi mengintrodusir istilah theo-demokrasi, yaitu suatu sistem pemerintahan demokrasi ilahi, karena di bawah naungannya kaum muslim telah diberi kedaulatan rakyat yang terbatas di bawah pengawasan Tuhan. ${ }^{53}$

\section{Simpulan}

Islam, sebagai sebagai agama penutup, hadir dengan membawa ajaran yang lengkap dan sempurna. Kesempurnaan ajaran Islam antara lain terietak pada; pertama, adanya ketentuan rinci dan baku mengenai hal-hal yang tidak terkena hukum perubahan dan pergantian sepanjang masa seperti masalah keimanan dan tata cara ibadah mahdhah; kedua, adanya ruang penggunaan pemikiran dalam hal-hal yang terkait dengan perubahan kondisi dan situasi yang dihadapi manusia. Aspek përtama bersifat rigid dan tidak memberikan peluang "penggunaan kreasi" pemikiran (ghair ma'kulat al-ma'na), sedang aspek kedua bersifat fleksibel, yang memberikan peluang pada kreasi pemikiran manusia (ma'kulat al-ma'na). Persoalan negara dan pemerintahan termasuk pada aspek yang kedua, dan karena itu penggunaan kreasi pemikiran merupakan kemestian agar senantiasa sesuai dengan kondisi dan situasi yang dihadapi umat manusia. Dalam ajaran Islam, menurut mayoritas ulama, negara dan pemerintahan merupakan instrumen untuk terlaksananya ajaran Islam dan terwujudnya tujuan-tujuan syariat Islam. Bila ajaran Islam dan tujuan syariat Isiam dapat terlaksana dan terwujud dalam suatu negara, maka secara ideal negara itu dapat disebut sebagai negara Islam. Dan bagaimana cara dan upaya melaksanakan dan mewujudkan ajaran islam itu diserahkan kepada kreasi pemikiran manusia, sementara ajaran Islam hanyalah memberikan prinsip-prinsip umum yang perinciannya diserahkan pada pemikiran atau ijtihad dan musyawarah di kalangan umat isiam.

\section{Daftar Pustaka}

Abu Faris, Muhammad Abd al-Qadir, alNidham al-Siyasi fi al-Islam, 1980.

Ahmad, Mumtaz (Ed.), Masalah-masalah Teori Politik Islam, Bandung: Mizan, 1994.

al-Anshary, Abd at-Hamid Ismail, Nidham alHukm fi al-Islam, Qatar: Dar al-Qatar, 1985.

al-Buthi, Said Ramadhan, al-Jihad fi al-Islam, Kaifa Nafhamuhu wa Kaifa Numarisuhu, Bairut: Dar al-Fikr al-Mu'ashirah, 1993.

s2 lihat Azhar Basyir, op. cit., hlm. 42-43. Dalam al-Qur'an: 6; 116 disebutkan; "Jika kamu ikuti saja kehendak kebanyakan orang di bumi ini, niscaya mereka menyesalkan kamu dari jalan Allah"

${ }^{53}$ Abul A'la al-Maududi, Sistem Politik Islam (Bandung: Mizan, 1995), hlm. 160 
al-Maraghi, Mustafa, Tafsir al-Maraghi, Julid II, Bairut: Dar al-Fikr, tt.

al-Maududi, Abul A'la, Sistem Politik Islam, Bandung: Mizan, 1995

Al-Mawardi, al-Ahkam al-Sulthaniyah, Bairut: Dar al-Fikr, tt.

al-Mubarak, Muhammad, Nidham al-Islam; alHukm wa al-Daulah, Bairut: Dar al-Fikr, 1989.

al-Syafi'l, Muhammad Idris, al-Kaukab alAzhar, Syarh al-Fiqh al-Akbar, Bairut: Dar al-Fikr, tt.

al-Syahrastani, Abd al-Karim, al-Milal wa alNihal, Bairut: Dar al-Fikr, tt.

al-Zuhaily, Wahbah, al-Figh al-Islamy wa Adilatuh, Jilid VI, Bairut: Dar al-Fikr, 1989.

al-Zuhaily, Wahbah, al-Quran Bunyatuh alTasyri'iyyah wa Khashaishuh alHadhariyyah, Bairut: Dar al-Fikr alMu'ashirah, 1993.

Amirudin, Hasbi, Konsep Negara Islam Menurut Fazlur Rahman, Yogyakarta: Ull Press, 2000.

An-Naim, Abdullah Ahmed, Dekonstruksi Syariah, Yogyakarta: LKiS, 1994

Asad, Muhamad, Sebuah Kajian tentang Sistem Pemerintahan Islam, Bandung: Bandung Pustaka, 1985.

Ash Shiddiegy, Tengku Muhammad Hasbi, Koleksi Hadis Hukum, juz 9, Semarang: Pustaka Rizki Putra, 2001

Audah, Abd al-Qadir, al-Islam wa Audha'una al-Siyasiyah, Kairo: al-Mukhtar al-
Islamy, tt.

Audah, Abd al-Qadir, al-Tasyri al-Jana'i alIslamy, Jilid I, Bairut: Dar al-Katib al'Araby, tt

Basyir, Azhar, Masalah Imamah dalam Filsafat Politik Islam, Yogyakarta: Fakultas Hukum Ull, 1988

Basyir, Azhar, Negara dan Pemerintahan dalam Islam, Yogyakarta: Ull Press, 2000

Eickelman, Dale F., dan James Piscatori, Politik Muslim, Wacana Kekuasaan dan Hegemoni dalam Masyarakal Muslim, Yogyakarta: Tiara Wacana, 1998

Haikal, Muhemmad Husein, al-Hukumah atIslamiyyah, Mesir: Dar al-Ma'arif, tt.

Hakim, Abd af-Hamid, al-Bayan, Bukit Tinggi: Nusantara, tt.

Hilmi, Mahmud, Nidham al-Hukmi al-Islamiy. Kairo: Dar al-Huda, 1978.

'led, Khalid Abdullah, Mabadi al-Tasyri alIslamy, Syirkat al-Hilal al-'Arabiyah, 1986.

Juergensmeyer, Mark, Menentang Negara Sekular, Bandung: Mizan, 1998.

Khalaf, Abd al-Wahab, IImu Ushul al-Figh, Kuwait: Dar al-Qalam, 1978

Khan, Qamaruddin, Pemikiran Politik Ibnu Taimiyah, Bandung: Pustaka, 2001.

Khomeini, Imam, Sistem Pemerintahan Islam, Jakarta: Pustaka Zahra, 2002.

Maarif, Syafit, al-Quran, Realitas Sosial dan Limbo Sejarah, Bandung: Mizan, 1985.

Maarif, Syafii, Islam dan Masalah Kenegaraan. 
Jakarta: LP3ES, 1987.

Musa, Muhammad Yusuf, Politik dan Negara dalam Islam, Surabaya: al-Ikhlas, tt.

Pulungan, Suyuti, Prinsip-prinsip Pemerintahan dalam Piagam Madinah, Jakarta: Rajawali Press, 1994.

Rais, Dhiauddin, Islam dan Khilafah, Bandung: Pustaka, 1985.

Rais, Dhiauddin, Teori Politik Islam, Jakarta: Gema Insani Press, 2001.

Shihab, M. Quraish, Tafsir Al-Misbah, vol. II, Jakarta: Lentera Hati, 2000.

Syaraf, Mühammad Jalal dan Ali Abd al-Mu'thi, al-Fikr al-Siyasi fi al-Islam,
Iskandariyyah: Dar al-Jami'at alMishriyyah, 1978.

Taimiyah, Ibnu, Siyasah Syar'iyah, Etika Politik Islam, Surabaya: Risalah Gusti, 1995.

Thalib, Shofi Hasan Abu, Tathbiq al-Syari'at al-Islamiyah fi al-Bilad al-'Arabiyah, Kairo: Dar al-Nahdhah al-'Arabiyah, 2001.

Ya'la, Abu, al-Ahkam al-Sulthaniyah, Bairut: Dar al-Fikr, 1994.

Zahrah, Muhammad Abu, Ushul al-Fiqh, Dar al-Fikr al-'Araby, tt.

Zallum, Abdul Qadim, Sistem Pemerintahan Islam, Bangil-Jatim: al-lzzah, 2002.

$\$ 08080$ 